OPEN

SUBJECT AREAS:

GEOCHEMISTRY

ORIGIN OF LIFE

PALAEONTOLOGY

GEOLOGY

Received

26 November 2013

Accepted

13 June 2014

Published

28 July 2014

Correspondence and requests for materials should be addressed to D.W. (david.wacey@ uwa.edu.au)

\section{Enhanced cellular preservation by clay minerals in 1 billion-year-old lakes}

\author{
David Wacey ${ }^{1}$, Martin Saunders², Malcolm Roberts ${ }^{2}$, Sarath Menon ${ }^{3}$, Leonard Green ${ }^{4}$, Charlie Kong ${ }^{5}$, \\ Timothy Culwick 6 , Paul Strother ${ }^{7} \&$ Martin D. Brasier ${ }^{6}$
}

\begin{abstract}
${ }^{1}$ Australian Research Council Centre of Excellence for Core to Crust Fluid Systems, Centre for Microscopy Characterisation and Analysis \& Centre for Exploration Targeting, The University of Western Australia, 35 Stirling Highway, Crawley, WA 6009, Australia, ${ }^{2}$ Centre for Microscopy, Characterisation and Analysis, The University of Western Australia, 35 Stirling Highway, Crawley, WA 6009, Australia, ${ }^{3}$ Department of Mechanical and Aerospace Engineering, Naval Postgraduate School, Monterey, CA 93943, USA, ${ }^{4}$ Adelaide Microscopy, The University of Adelaide, SA 5005, Australia, ${ }^{5}$ Electron Microscopy Unit, University of New South Wales, NSW 2052, Australia, 'Department of Earth Sciences, University of Oxford, South Parks Road, Oxford, OX 1 3AN, UK, ${ }^{7}$ Department of Earth and Environmental Sciences, Boston College, Weston, MA 02493, USA.
\end{abstract}

Organic-walled microfossils provide the best insights into the composition and evolution of the biosphere through the first 80 percent of Earth history. The mechanism of microfossil preservation affects the quality of biological information retained and informs understanding of early Earth palaeo-environments. We here show that 1 billion-year-old microfossils from the non-marine Torridon Group are remarkably preserved by a combination of clay minerals and phosphate, with clay minerals providing the highest fidelity of preservation. Fe-rich clay mostly occurs in narrow zones in contact with cellular material and is interpreted as an early microbially-mediated phase enclosing and replacing the most labile biological material. K-rich clay occurs within and exterior to cell envelopes, forming where the supply of Fe had been exhausted. Clay minerals inter-finger with calcium phosphate that co-precipitated with the clays in the sub-oxic zone of the lake sediments. This type of preservation was favoured in sulfate-poor environments where Fe-silicate precipitation could outcompete Fe-sulfide formation. This work shows that clay minerals can provide an exceptionally high fidelity of microfossil preservation and extends the known geological range of this fossilization style by almost $500 \mathrm{Ma}$. It also suggests that the best-preserved microfossils of this time may be found in low-sulfate environments.

emarkable preservation of carbonaceous soft-bodied organisms in the geological record reveals unique details about ancient biotas, ecosystems and biogeochemical cycles. Such lagerstätten (i.e., a sedimentary deposit with exceptional fossil preservation) commonly preserve (micro)fossils in silica (e.g., Gunflint biota $^{1}$ ), pyrite (e.g., Hunsrück slate biota ${ }^{2}$ ) or phosphate (e.g., Doushantou biota ${ }^{3}$ ). In recent years, the ability of alumino-silicates (e.g., clay minerals and their diagenetic and metamorphic derivatives) to preserve fine scale features of soft-bodied organisms has received increased attention ${ }^{4-21}$.

Fossil preservation in alumino-silicates has been widely reported from the Paleozoic ${ }^{5-7,10,12,16}$ and terminal Neoproterozoic (i.e., Ediacaran) $)^{14,17,18,21}$ rock record. There, a variety of Fe-, $\mathrm{Mg}$-, and K-rich alumino-silicates have been found in close association with both macrofossils ${ }^{5-7,10,12,16-18,21}$ and, more rarely, microfossils ${ }^{14}$. Subsequent diagenesis ${ }^{11}$ and metamorphism ${ }^{13}$ often complicate interpretations of the exact role, if any, that clays played in ancient fossil preservation, so that high resolution petrographic and textural studies are required to determine an authigenic from detrital or later metamorphic origin. Nevertheless, microbes and microbial biofilms have frequently been implicated as drivers of authigenic clay mineral precipitation and enhanced preservation of soft-bodied fossils in the geological recorde.g, 14,17,22.

Support for the role of authigenic clay precipitation in organism preservation comes both from experiments $\mathrm{s}^{23-25}$ and field studies of modern environment ${ }^{26-33}$. These show that microbial mediation of clay minerals is relatively common and energetically favourable. A number of such studies ${ }^{23,26,27,30}$ have focused on microbially mediated Fe-rich clay minerals (e.g., berthierine, chamosite, nontronite, glauconite); these have been shown to form in natural lakes ${ }^{26}$, rivers ${ }^{30}$, and geothermal settings ${ }^{27}$. Microbes and their associated EPS have also been shown to help catalyse a wide range of other alumino-silicates including kaolinite $e^{25}$, halloysite ${ }^{34}$, plus Mg-rich ${ }^{31,32}$ and K-rich ${ }^{28}$ clays. Microbial metabolism may also be capable of changing the composition of clay minerals, as demonstrated by the transformation of Fe-rich smectite to interlayered K-rich smectite-illite via an iron-reduction metabolism ${ }^{35}$. While Fe appears to be particularly susceptible to interacting with organic surfaces, likely due 


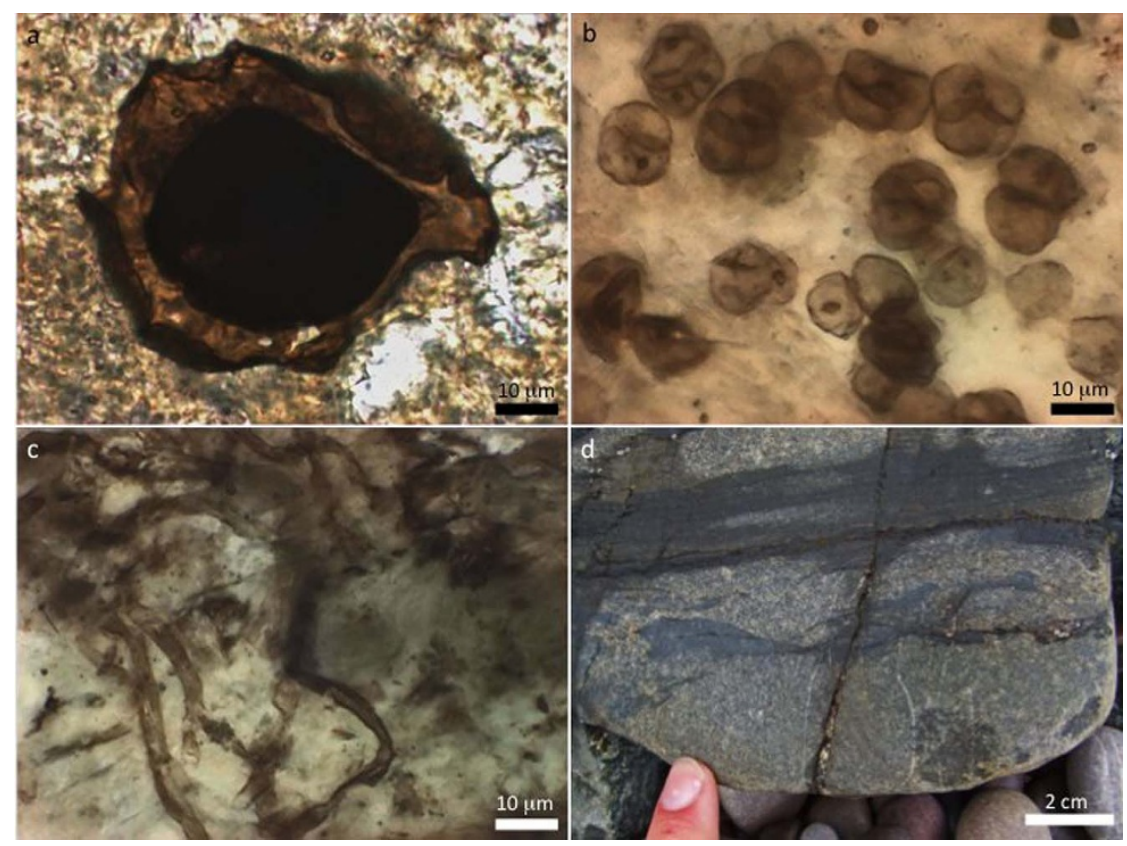

Figure $1 \mid$ Well preserved $\sim 1000$ Ma carbonaceous fossils (a-c) found within phosphate (d) of the Torridon Group. (a) Pterospermopsimorpha sp., here interpreted as a eukaryote with a pale outer vegetative envelope and dark internal cyst (cf. ref. 43). (b) A loosely arranged colony of Myxococcoides sp. cells dividing into diads and tetrads, showing dark interior spots that likely formed during cytoplasmic decay of prokaryotic cell contents. (c) Empty filamentous tubes of Siphonophycus sp., here regarded as prokaryotic sheaths. (d) Layers of phosphate within siltstone of the Cailleach Head Formation, at Cailleach Head.

to its multivalent nature, favourable hydration energy and hydrated radius $^{36}$, the exact authigenic minerals that precipitate under the influence of microbial-mediation will depend on a number of factors including, $\mathrm{pH}$, Eh, sulfate concentration, availability of reactive ions in the ambient water, plus the type of biological substrate and hence its relative affinity for specific ions ${ }^{29}$.

Despite the above work, much remains to be understood about the processes involved in fossilization by clay minerals and the types of organisms that may be capable of mediating clay mineral precipitation. Save for rare occurrences in Ediacaran sediments ${ }^{14}$, the association of clay minerals with microfossils has yet to be described from Precambrian strata, so the true antiquity of this mode of fossilization remains to be deduced. In addition, fossilization by clay minerals appears to require rather specific environmental parameters. Hence, new discoveries of this style of fossilization should help to constrain palaeo-environmental and biospheric conditions before the Cambrian. This contribution extends the record of remarkable preservation in clay minerals by almost $500 \mathrm{Ma}$, back to terrestrial lacustrine environments of the c. $1000 \mathrm{Ma}$ Torridon Group of Northwest Scotland.

\section{Results}

Microfossil occurrence and morphology. Sediments of the Proterozoic Torridon Group are found in northwest Scotland where they unconformably overlie Archean to Paleoproterozoic Lewisian metamorphic rocks and, in places, sedimentary rocks of the $c$. $1200 \mathrm{Ma}$ Stoer Group. They are, in turn, unconformably overlain by lower Cambrian sedimentary deposits of the Eriboll Formation $^{37,38}$. The Torridon Group has been dated close to its base (Diabaig Formation) at $994 \mathrm{Ma} \pm 48 \mathrm{Myr}^{39}$, and comprises a clastic sequence of coarse sandstones with minor shales that were deposited in terrestrial fluvio-lacustrine environments ${ }^{38,40-44}$. Wellpreserved microfossils occur as compressed, organic-walled microfossils (OWMs, or, palynomorphs) in laminated shales and as 3-dimensionally preserved OWMs housed in laminated phosphatic nodules within lacustrine grey shales of the Diabaig and Cailleach
Head Formations (Fig. 1; see also refs. 37, 43, 44). At Lower Diabaig and on the southern shoreline of Loch Torridon, the laminated shales preserve microbially induced sedimentary structures (MISS) which typically retain a reticulate "elephant-skin" texture ${ }^{40,43}$. Where phosphatization has occurred, microfossils can be observed in place within the MISS. These autochthonous microfossils occur most commonly as isolated individual cells and cell colonies, but isolated empty sheaths (non-septate filaments), and, rarely, septate filaments are also scattered throughout the laminae ${ }^{44}$. Overall, the Torridonian biota consists of more than 40 morphologically distinct morphospecies corresponding to a mix of unicellular and colonial prokaryotes and eukaryotes ${ }^{43}$. Cellular-level complexity ranges from simple single-walled forms, to thicker-walled cysts enclosed within vegetative cell walls, to a mix of asymmetric structural features associated with larger cells and pre-determined excystment openings ${ }^{43}$. Additional levels of multicellular complexity are found in multicellular balls of cells found in phosphatic nodules at Lower Diabaig. Specimens analysed here at high spatial resolution sample this morphological diversity of isolated eukaryotic cells (up to c. $130 \mu \mathrm{m}$ in diameter), cells with multiple wall layers, a multicellular ball, clusters of simple coccoids and non-septate filaments.

Mineral zonation. Clay minerals and calcium phosphate dominate the mineral assemblage in the vicinity of Diabaig and Cailleach Head microfossils, and these frequently occupy distinct micro- to nanoscale zones around and within fossilized organic material.

One kind of Cailleach Head microfossil has a thicker inner wall and thinner outer wall (Fig. 2; Fig. S1), here interpreted as a eukaryotic cyst enclosed within a vegetative cell wall ${ }^{\text {cf.43 }}$, and serves to illustrate the most common pattern of mineral zonation. Fe-rich clay (with lesser and variable $\mathrm{Mg}$ ) is found in between the inner cyst and outer cell wall (Fig. 2c, blue zone), partly replacing the latter (e.g., Fig. $2 c$, arrow), and extending up to c. $2 \mu \mathrm{m}$ beyond the cell wall. Moving away from the outer wall, the Fe-rich clay decreases rapidly in abundance and grades into a zone dominated by calcium phosphate (Fig. 2c, green zone). It is notable that the calcium phosphate is rarely found in direct contact with the organic material of either the 

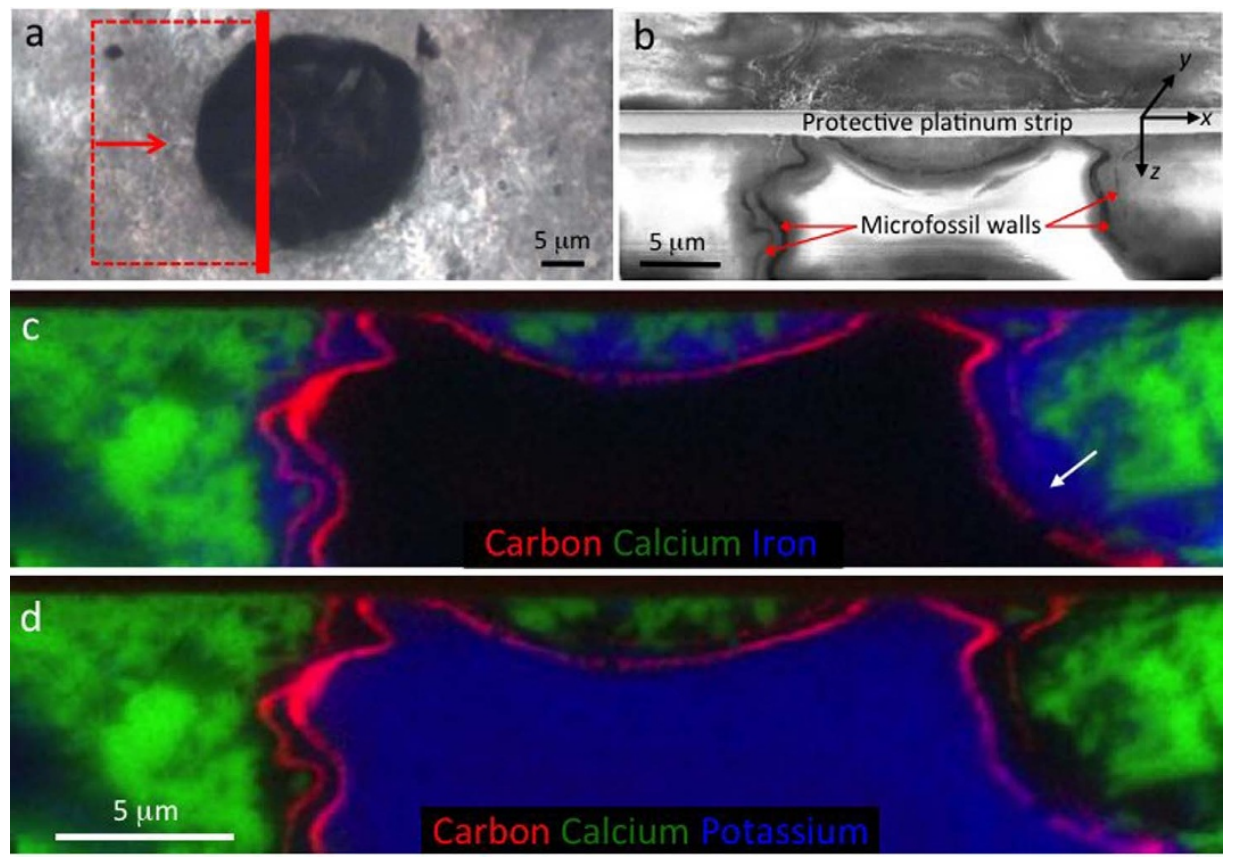

Figure $2 \mid$ Mineral zonation in and around a well-preserved eukaryote microfossil from the Cailleach Head Formation. (a) Microfossil overview showing the location of the FIB-milled area and direction of view for (b-d). (b) Secondary electron image showing the FIB-milled face below the surface of the thin section (lower half of image). (c-d) Energy-dispersive X-ray (EDS) elemental maps of the FIB-milled face shown in (b): carbon (red) represents the organic microfossil walls, highlighting a thick inner cyst wall and thinner outer vegetative cell wall; and calcium (green) represents calcium phosphate. In (c), iron (blue) represents Fe-rich clay, occurring between the two microfossil walls, replacing parts of the outer wall (arrow), and continuing for 1$2 \mu \mathrm{m}$ outside the outer wall. In (d), potassium (blue) represents K-rich clay restricted to the interior of the vesicle. EDS spectra and electron diffraction patterns giving the complete chemistry of each of these minerals are shown in Figures 3 and 7.

cell or cyst walls. The interior of the cyst is also infilled with clay, but of a K-rich, rather than Fe-rich, composition (Fig. 2d, blue zone). Microprobe elemental maps of an extended field of view including part of this microfossil (Fig. S1; arrow in BSE image points to dark outline of the surface expression of the microfossil) confirm that concentrations of $\mathrm{Fe}, \mathrm{Mg}$ and $\mathrm{K}$ are all elevated in and around the microfossil (Fig. S1, arrows in $\mathrm{Fe}, \mathrm{Mg}$ and $\mathrm{K}$ maps) compared to most of the sedimentary matrix, suggesting a causal link between the organism and the Fe-Mg- and K-rich clays.

This mineral zoning pattern can vary between microfossil specimens. Hence, a second multi-walled coccoid specimen from the Cailleach Head Formation (Fig. 3) is likewise infilled with a K-rich clay, but this mineral also extends into the inter-wall region between the inner cyst and the outer cell (Fig. 3a, green K map; Fig. 3b, EDS spectrum $\mathrm{S} 1$ ). Fe-rich clay (sometimes also with minor $\mathrm{Mg}$ ) is less prominent around this specimen, but still occurs in contact with the outer cell wall (Fig. 3a, orange Fe map; Fig. 3b, EDS spectrum S2). Calcium phosphate is again the dominant mineral found exterior to the specimen and, in this case, occurs in direct contact with parts of the outer cell wall (Fig. 3a, purple Ca map and green P map; Fig. 3b, EDS spectrum S3).

Non-septate filaments from the Diabaig Formation, here interpreted as tubular exopolymeric sheaths of filamentous bacteria ${ }^{\text {cf. }}{ }^{44}$, are frequently infilled by Fe-rich silicates. Low spatial resolution elemental maps show filamentous morphologies approximately replicated by Fe-rich silicates (Fig. 4a, arrows in BSE image and red Fe map). Higher resolution STEM-EDS maps confirm infilling by Fe-rich silicates, plus lesser volumes of K-rich silicates (Fig. 4b, orange Fe map and green $\mathrm{K}$ map). Unlike the coccoid microfossils, distinct carbonaceous sheath walls are rarely seen, but elevated concentrations of carbonaceous material are seen intermixed with the Fe-silicates in places (Fig. 4b, blue $\mathrm{C}$ map). There is a distinct increase in the $\mathrm{Mg}$ : Fe ratio on the right hand portion of the Fe-silicate zone (Fig. $4 \mathrm{~b}$, arrow in blue $\mathrm{Mg}$ map), reflecting a change in relative availability of these ions here; the boundary across which this ratio changes could represent the former position of the outer margin of the sheath. Potassium distribution is much less influenced by the microfossil morphology than Fe or $\mathrm{Mg}$ in this example. The matrix is, once again, dominantly phosphatic with minor clastic material caught up within it (Fig. 4a and b).

Fe-rich silicates are also found infilling the outer compartments of complex, multicellular balls from the Diabaig Formation (Fig. 5). Microprobe elemental maps encompassing part of this microfossil plus a large area of matrix demonstrate the extreme localization of $\mathrm{Fe}$ to the outer zone of the microfossil (Fig. 5a, arrow in Fe map). K also appears to be enriched in part of the microfossil (Fig. 5a, arrow in $\mathrm{K}$ map) but it is also found in small grains throughout much of the matrix. Higher resolution STEM-EDS data (Fig. 5b), from the same microfossil, show three distinct mineral zones within the microfossil; an outer zone of Fe-rich silicate (with minor $\mathrm{Mg}$ that was not detected in the larger microprobe maps; Fig. 5b, bottom zone picked out in orange in the Fe map; Fig. 5c, EDS spectrum S1), an intermediate zone of K-rich silicate (Fig. 5b, narrow central zone picked out in green in the K map; Fig. 5c, EDS spectrum S2), and an inner, central zone of silica (Fig. 5b, top zone picked out bright green in $\mathrm{Si}$ map). These changes in mineralogy occur across boundaries between adjacent cellular compartments (Fig. 5b, carbon map; Fig. S4a, c, d).

Some microfossil specimens are infilled, either partly or entirely, with phosphate. For example, a very large coccoid of some $130 \mu \mathrm{m}$ diameter (probable eukaryote ${ }^{\text {cf.43,44}}$ ) from the Diabaig Formation is mostly preserved in calcium phosphate, with clay minerals (mostly K-rich plus minor Fe-rich) restricted to narrow zones next to its thick outer wall (Fig. S2). In addition, many small coccoids of inferred bacterial affinity ${ }^{\text {cf.44 }}$, both single specimens and clusters, are infilled by both clay minerals and phosphate. Here, calcium phosphate dominates, but Fe-silicate is commonly found close to, or in contact with, the remains of cell walls (Fig. 6, blue zones in c and e). K-rich clay can also occur in these specimens (Fig. S3), while calcium phosphate 


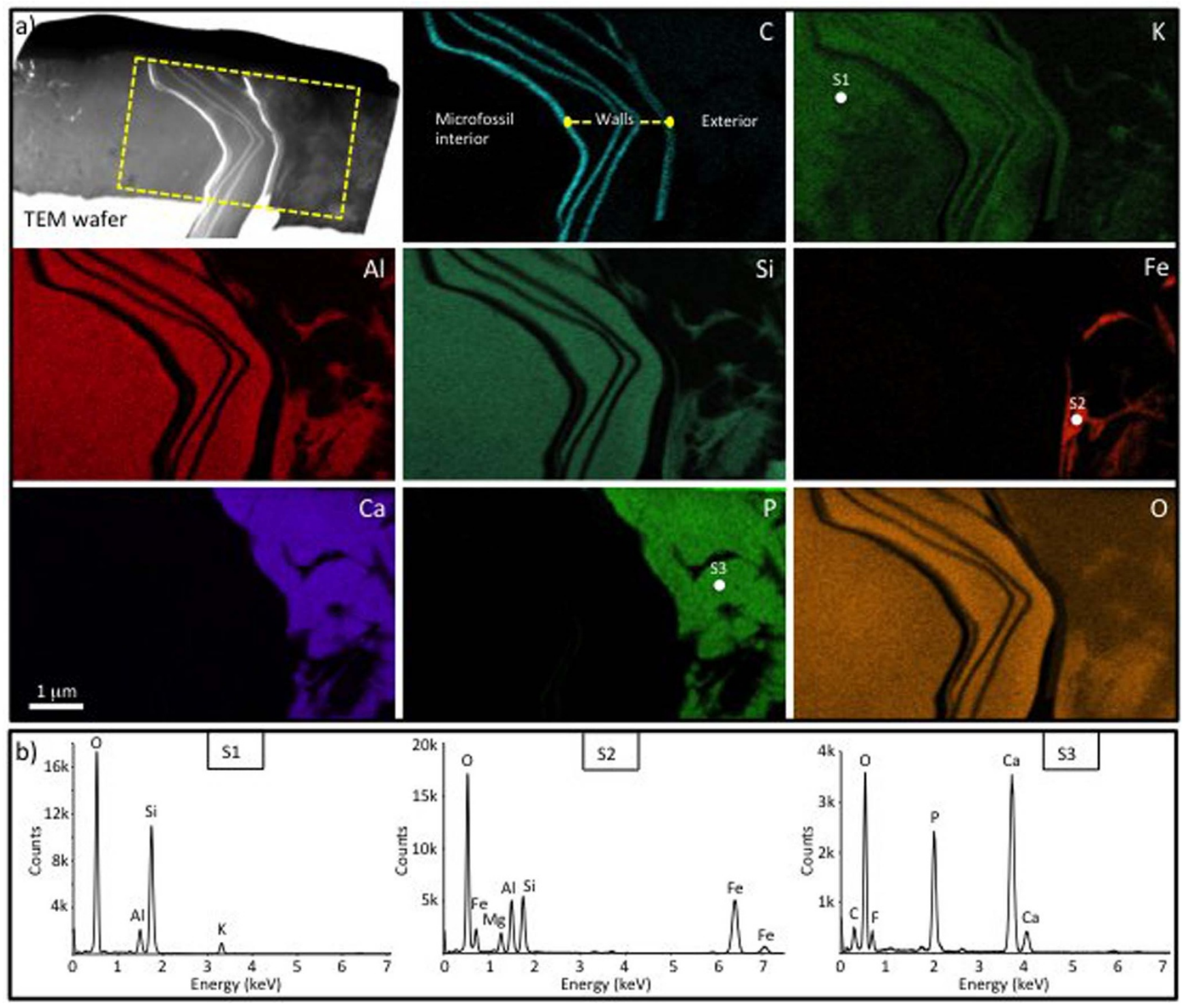

Figure $3 \mid$ Mineral zonation associated with a eukaryote microfossil (Leiosphaeridia crassa) with multi-layered walls from the Cailleach Head Formation. (a) Overview of a focused ion beam (FIB) milled TEM wafer through the microfossil wall, plus ChemiSTEM elemental maps of the boxed area. Note the multiple wall layers picked out by the carbon map. The interior of the microfossil and the area between the wall layers is filled with K-rich clay. There is also some $\mathrm{K}$ in the carbonaceous microfossil walls themselves and minor K-rich clay outside of the microfossil. Fe-rich clay and calcium phosphate occur in contact with the outer wall of the microfossil, with the latter being the dominant phase outside of the microfossil. (b) STEM-EDS spectra of the K-rich clay (S1), Fe-rich clay (S2) and calcium phosphate (S3) phases associated with the microfossil. Note the presence of F and C peaks in $\mathrm{S} 3$ indicative of francolite (carbonate fluorapatite). The positions of the spectral analyses are marked in the K, Fe and P maps respectively.

again makes up most of the enclosing matrix away from the immediate vicinity of the cells (Fig S3).

Mineral identification. The ubiquitous calcium phosphate phase is francolite (carbonate fluorapatite), demonstrated by its mode of occurrence, presence of distinct $\mathrm{F}$ and $\mathrm{C}$ peaks in STEM-EDS spectra (Fig. 3b), and its selected area electron diffraction pattern in the TEM (Fig. 7a). Firm identifications of the clay mineral phases are more difficult owing to their small size and restricted distribution. The Fe-rich silicate is mostly nano-crystalline, with selected area electron diffraction patterns from groups of these grains producing ring patterns that are consistent with both chamosite-like and berthierine-like clay ${ }^{45}$. Some larger grains show the $1.4 \mathrm{~nm}$ interlayer spacing plus electron diffraction spot patterns consistent with chamosite (Fig. $7 \mathrm{~b}-\mathrm{c}$ ), while others have d-spacings most consistent with berthierine (Fig. 7d). Nano-crystalline clays with chemistries similar to chamosite and berthierine are common biologically-induced $\mathrm{Fe}$-rich silicate precipitates in modern environments $^{28,46}$. Chamosite $\left[\left(\mathrm{Fe}_{5} \mathrm{Al}\right)\left(\mathrm{Si}_{3} \mathrm{Al}\right) \mathrm{O}_{10}(\mathrm{OH})_{8}\right]$ is the idealized $\mathrm{Fe}$ end member of the Fe-Mg chlorite solid solution series, but these microbially-mediated Fe-rich silicates rarely have the ideal chamosite structure ${ }^{28}$. Hence, they are best described as chamosite-like clays, typically containing variable proportions of $\mathrm{Mg}$ (as observed here). Berthierine has a chemical composition comparable to chamosite, but a structure closely resembling serpentine ${ }^{47}$.

The K-rich clay phase is amorphous in places (Fig. 7e) but more commonly nano-crystalline in habit (Fig. 7f). Where electron diffraction patterns can be obtained in the TEM (Fig. 7f), they show a set of d-spacings (e.g., $\sim 1 \mathrm{~nm}, \sim 0.45 \mathrm{~nm}, \sim 0.31 \mathrm{~nm}$ ) consistent with the K-rich clay, illite ${ }^{45}$. K-rich phases similar to illite have been reported from modern microbially-mediated settings ${ }^{28}$. Authigenic illite has also previously been reported from Torridon sediments, 


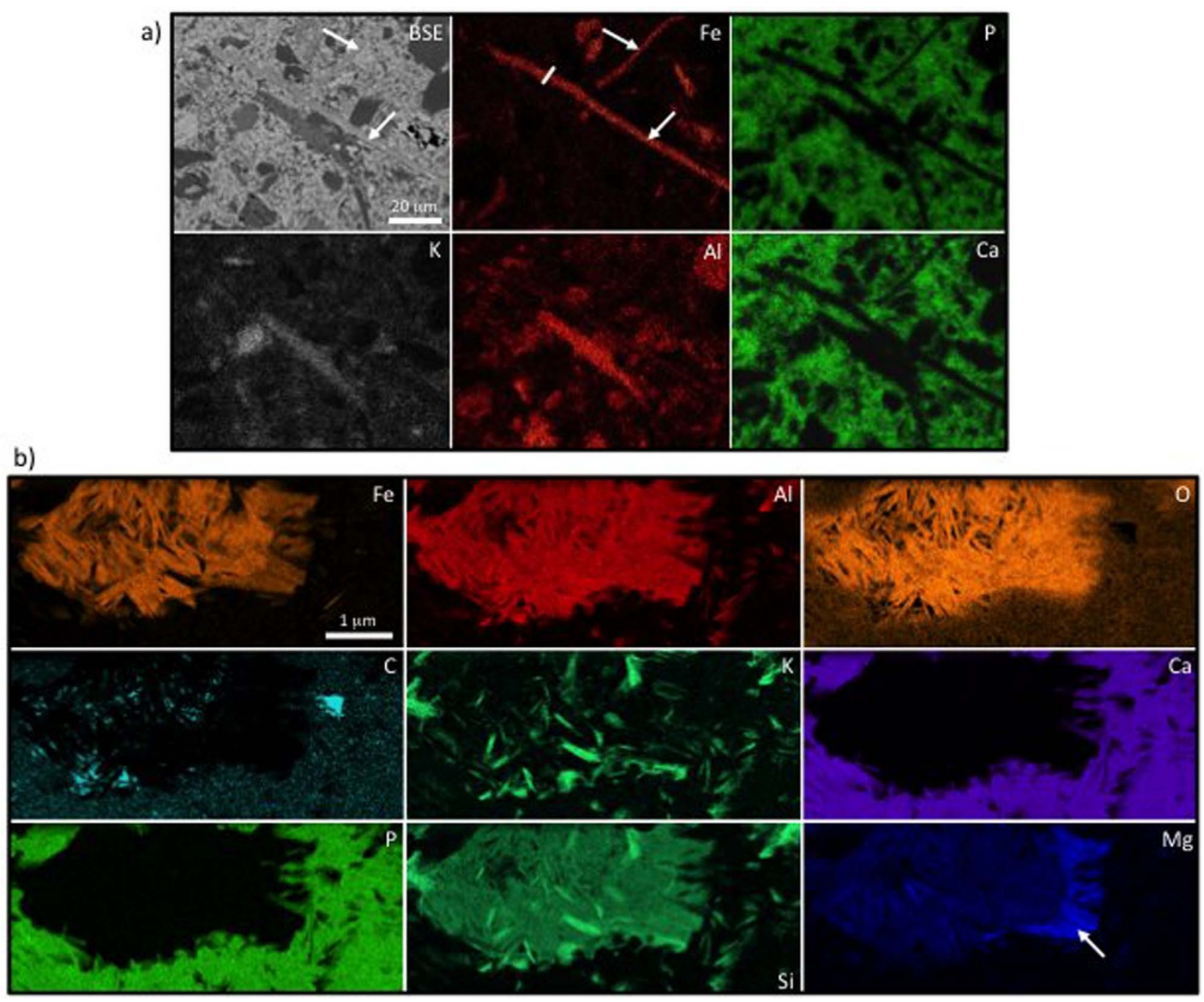

Figure $4 \mid$ Mineral zonation in the vicinity of non-septate filaments from the Diabaig Formation. (a) Backscattered electron image and SEM-EDS maps from a Diabaig phosphatic layer containing at least two non-septate filaments (arrows). Note the enrichment of iron in the filaments, plus the matrix dominated by calcium phosphate. The white line in the iron map indicates the approximate position of the TEM wafer mapped in (b). (b) ChemiSTEM elemental maps of a cross section through a Diabaig filament. Note that Fe-silicates replicate the approximate morphology of the filament and there are elevated carbon concentrations in part of this region. The increase in $\mathrm{Mg}$ : Fe ratio in the clay mineral (arrowed zone in $\mathrm{Mg}$ map) may represent the transition from filament interior to exterior.

where its low boron content has been used as part of a suite of evidence for the non-marine nature of the Torridon Group ${ }^{48}$.

Electron microprobe analysis of Torridon thin sections shows that the background sediment outside of the phosphate nodules and bands mainly comprises quartz, Na-feldspar, plus minor biotite and K-feldspar, largely derived from continental weathering of the underlying Lewisian basement and reworked Torridon age sediments $^{38,48}$. Some of this background sediment is also suspended within the phosphatic nodules (e.g., Fig. S1), where it tends to fine upwards, smoothly and conformably ${ }^{44}$, consistent with entrapment during primary, in situ, phosphate mineralization within the lake sediments.

Fidelity of organic preservation. The Torridon microfossils show a remarkably high fidelity of organic preservation, with quality that appears to be greatest when found directly in contact with clay minerals. Numerous clumps of labile carbonaceous material, consistent with shrunken cytoplasm, are preserved within the interior of simple coccoids (Fig. 8). All but one of these have proved to be preserved in clay rather than phosphate. Within larger eukaryotes, the same holds true for the preservation of multiple organic layers, each separated by slivers of clay mineral (Figs. 2, 3, S4). This contrasts calcium phosphate crystal nucleation seen within cells, which frequently modifies cell wall architecture during its growth causing bulging and bending of still flexible walls (Fig. 8d). This phosphate typically occurs as euhedral, tabular or prismatic crystals that are hexagonal in cross section and up to $c$. $6 \mu \mathrm{m}$ in length. The higher fidelity of organic preservation seen here in clay minerals may be explained by their grain size $e^{\text {cf.49, }}$, since they are almost always smaller than the phosphate crystals. However, it may also be due to the advantageous mechanism of clay mineral precipitation; the clays occur either as amorphous phases or as small stacks of plates aligned sub-parallel to the cellular material (Fig. S4), meaning that the disturbance of organic ultrastructure was less. Calcium phosphate precipitation then helped to provide the rigid coating needed to prevent collapse of the cell envelopes during early diagenesis, preventing compaction and conserving the remarkable 3D morphology.

Despite this high fidelity of preservation, some cellular features have undoubtedly been lost. The organic material that we now see likely represents the more recalcitrant parts of cell, vesicle and cyst walls. Other components of the organisms, for example, the more 

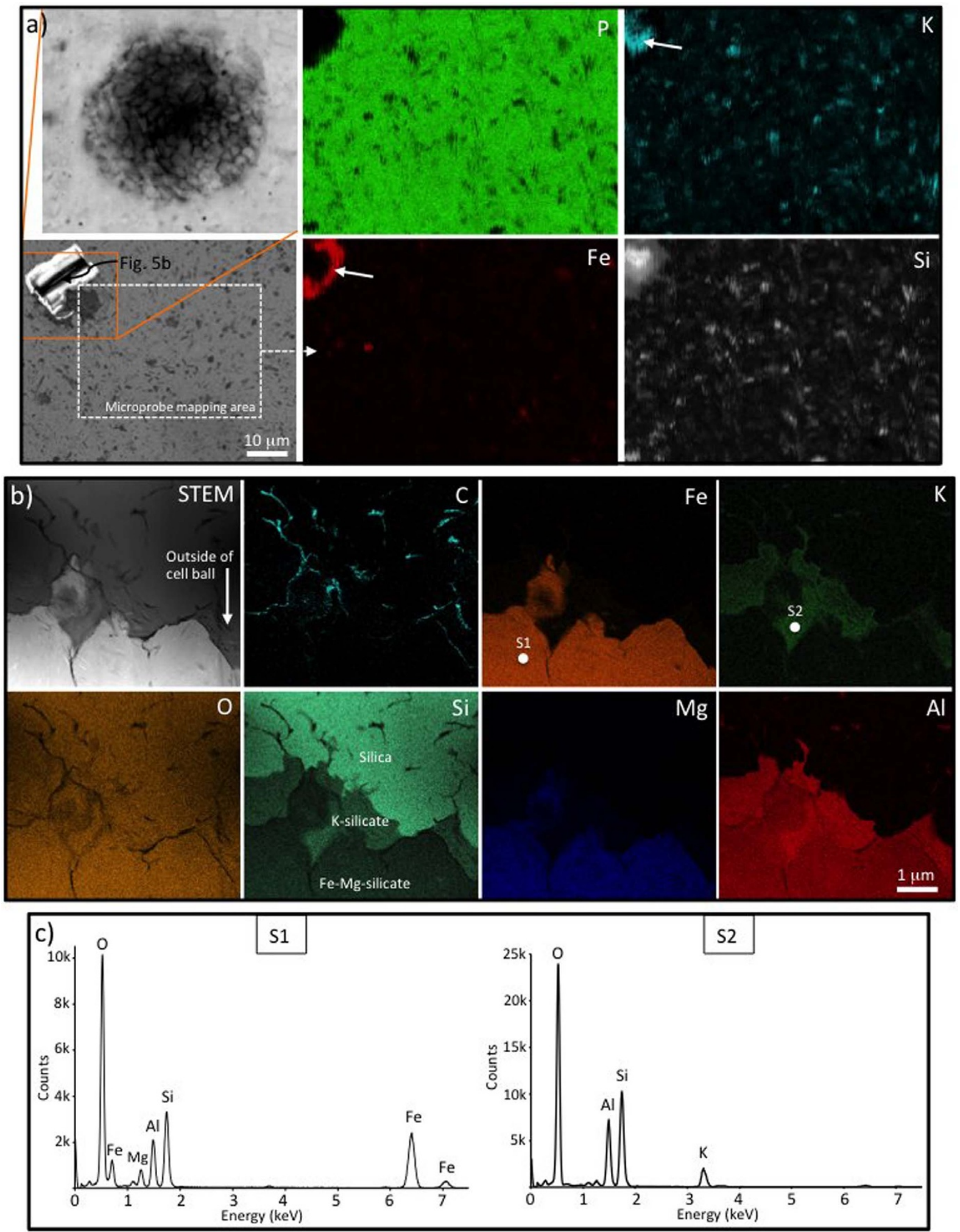

Figure $5 \mid$ Distribution of minerals fossilizing a complex ball of cells from the Diabaig Formation. (a) Microprobe EDS elemental maps encompassing approximately one quarter of the ball of cells (top left of the elemental maps), plus a large area of phosphate nodule matrix. Note the significant enrichment and restriction of Fe to the outer zone of the microfossil (arrow in Fe map). K-rich silicates are also found more centrally in the microfossil (arrow in K map) but also occur as small grains within the phosphate nodule matrix. The light micrograph (top left image) shows the morphology of the ball of cells prior to the in situ analyses, while the SEM image (bottom left) shows the ball of cells after extraction of the FIB wafer used in (b) (bright area in top left of image) plus the region element mapped (dashed box). (b) STEM image and ChemiSTEM elemental maps of part of the same ball of cells (from the FIB milled wafer extracted from the area indicated in (a)). These show a clear outer zone of Fe-rich (plus minor Mg) silicate, then a narrow zone of $\mathrm{K}$ rich silicate, and central zone of silica (all labeled on green Si map). The mineralogy changes across distinct cell wall boundaries (highlighted in the pale blue C map). (c) STEM-EDS spectra of the Fe-rich clay (S1) and K-rich clay (S2) phases infilling the microfossil. The positions of these spectra are marked in the $\mathrm{Fe}$ and $\mathrm{K}$ maps respectively. 

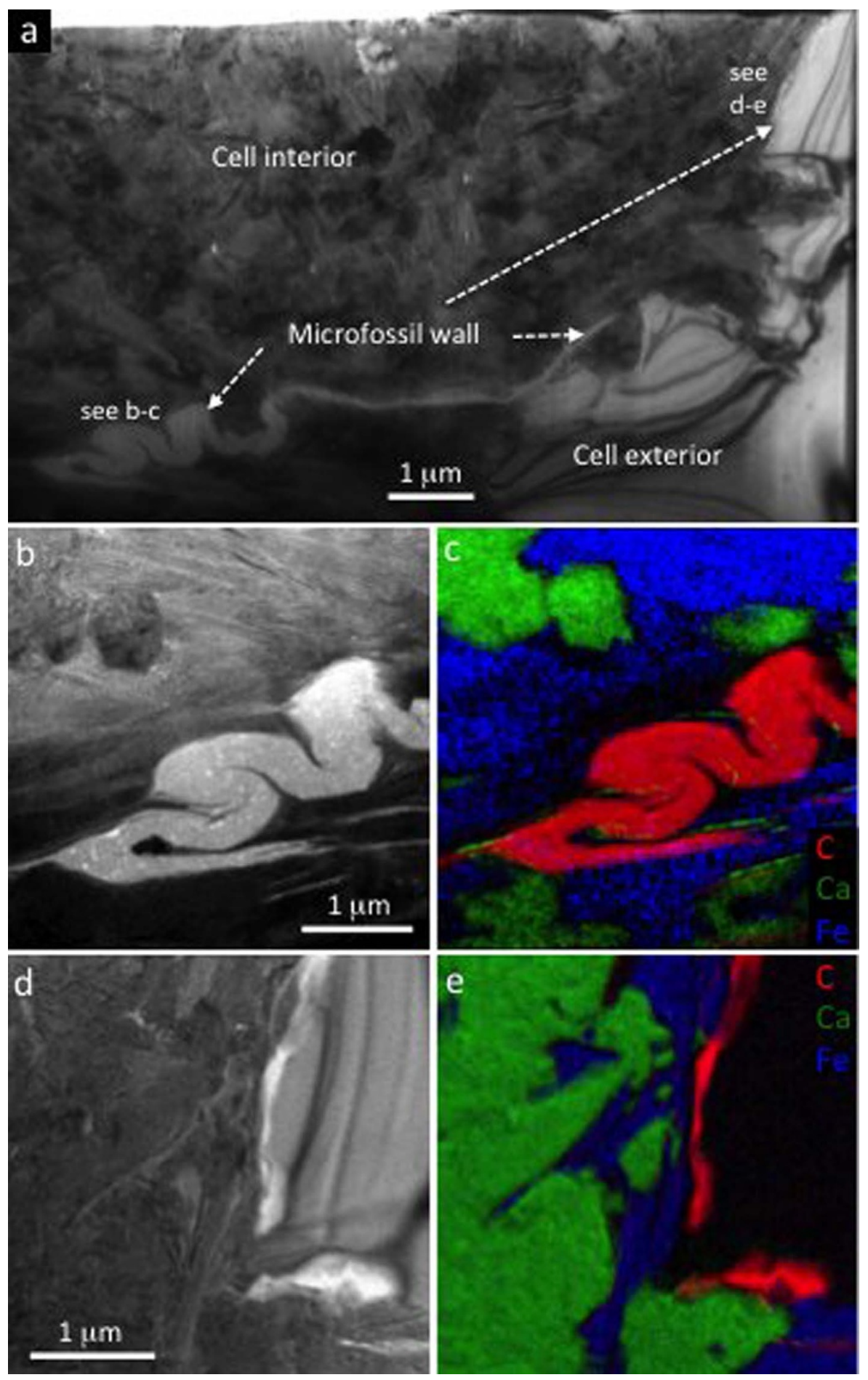

Figure 6 | Nano-scale structure and chemistry of a typical prokaryote cell from the Cailleach Head Formation. (a) Bright-field TEM image of an ultrathin section through part of a coccoid cell. The cell wall runs from top right to bottom left of the field of view, and this is folded (lower left) and fractured (right). (b, d) Bright-field TEM and (c, e) energy-filtered TEM elemental maps of two parts of the cell wall and surrounding minerals. Calcium (green) represents calcium phosphate, iron (blue) represents Fe-rich clay, and carbon (red) represents organic material of the cell wall. Both calcium phosphate and Fe-rich clay occur in direct contact with the cell wall, and are inter-grown both within and outside the cell. Quartz occurs outside the cell (black area in (e)) where the cell wall is more poorly preserved.

labile wall layers, coatings of exopolymeric substances and most of the cell contents have either been replaced by clay and phosphate or lost completely. In some specimens (e.g., Fig. 2), Fe-silicate distributions suggest localized replacement of labile wall layers and/or exopolymeric substances. In other specimens (e.g., Fig. 8b, d) the patterns of phosphate crystal growth suggest nucleation upon inner parts of cell walls or replacement of cell contents.

\section{Discussion}

Clay minerals are common components of sedimentary rocks and these may derive from detrital sources, or from authigenic or late stage (e.g., metamorphic) mineral growth. While detrital clay minerals have been reported from Torridon sediment ${ }^{38,48}$, clays preserving these Torridon microfossils do not show detrital textures or patterns. Instead, they show distinctive chemical compositions, and distribu- 

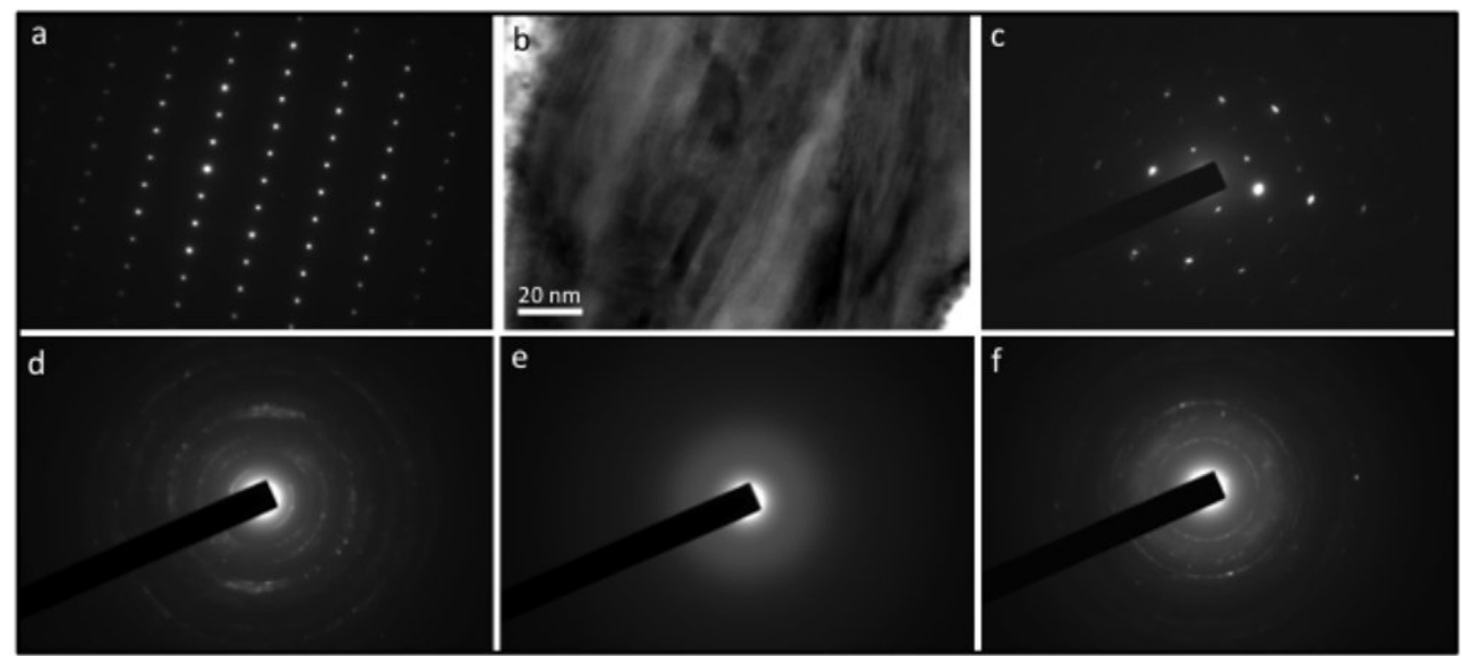

Figure $7 \mid$ Mineral identification. (a) Single crystal selected area electron diffraction (SAED) pattern from the calcium phosphate phase located just outside the microfossil in Figure 3; this spot pattern ${ }^{\text {cf.45 }}$, plus the presence of F and C in the EDS spectrum (Fig. 3b) is indicative of francolite, the typical calcium phosphate mineral in sedimentary phosphorites. (b) High resolution TEM image of the Fe-rich silicate mineral associated with the outer wall of the microfossil illustrated in Figure 3. This shows (as series of parallel lines) the $\sim 1.4 \mathrm{~nm}$ interlayer spacing of a $2: 1$ ordered clay mineral of the chlorite group, and is consistent with the Fe-rich clay mineral chamosite ${ }^{45}$. (c) SAED pattern of the same mineral; the spot pattern is also consistent with chamosite $^{45}$. (d) Selected area electron diffraction pattern from the Fe-rich silicate mineral infilling part of the microfossil in Figure 5; d-spacings obtained from the ring pattern show close matches to both the Fe-rich clay minerals berthierine and chamosite. It is not possible to distinguish these for certain because of the inherent accuracy of the electron diffraction technique. However, the d-spacing at $\sim 0.265 \mathrm{~nm}$, when present, consistently shows a closer fit to berthierine $(0.267 \mathrm{~nm})$ than chamosite $(0.260 \mathrm{~nm})$ (http://www.mindat.org). (e) SAED pattern from the K-rich silicate associated with the inner wall of the microfossil in Figure 3; the absence of spots or narrow rings in the pattern indicates that the mineral is amorphous in this area. (f) SAED pattern from part of the K-rich silicate towards the centre of the microfossil interior in Figure 3; the ring pattern is consistent with the K-rich clay illite ${ }^{45}$.

tions that are closely related to the organic materials themselves (e.g., Figs. 2-6; Fig. S1): for example, Fe-rich clays can completely encase the exterior surfaces of microfossils, while K-rich clays can be localized to interiors of the same specimens (e.g., Fig. 2). Nor do the microfossil-related clays show features consistent with a late stage metamorphic origin, unlike those displayed by clay minerals associated with remarkable organic preservation in the Burgess Shale $e^{11,13}$. In the latter, more labile organic tissues are commonly replicated by
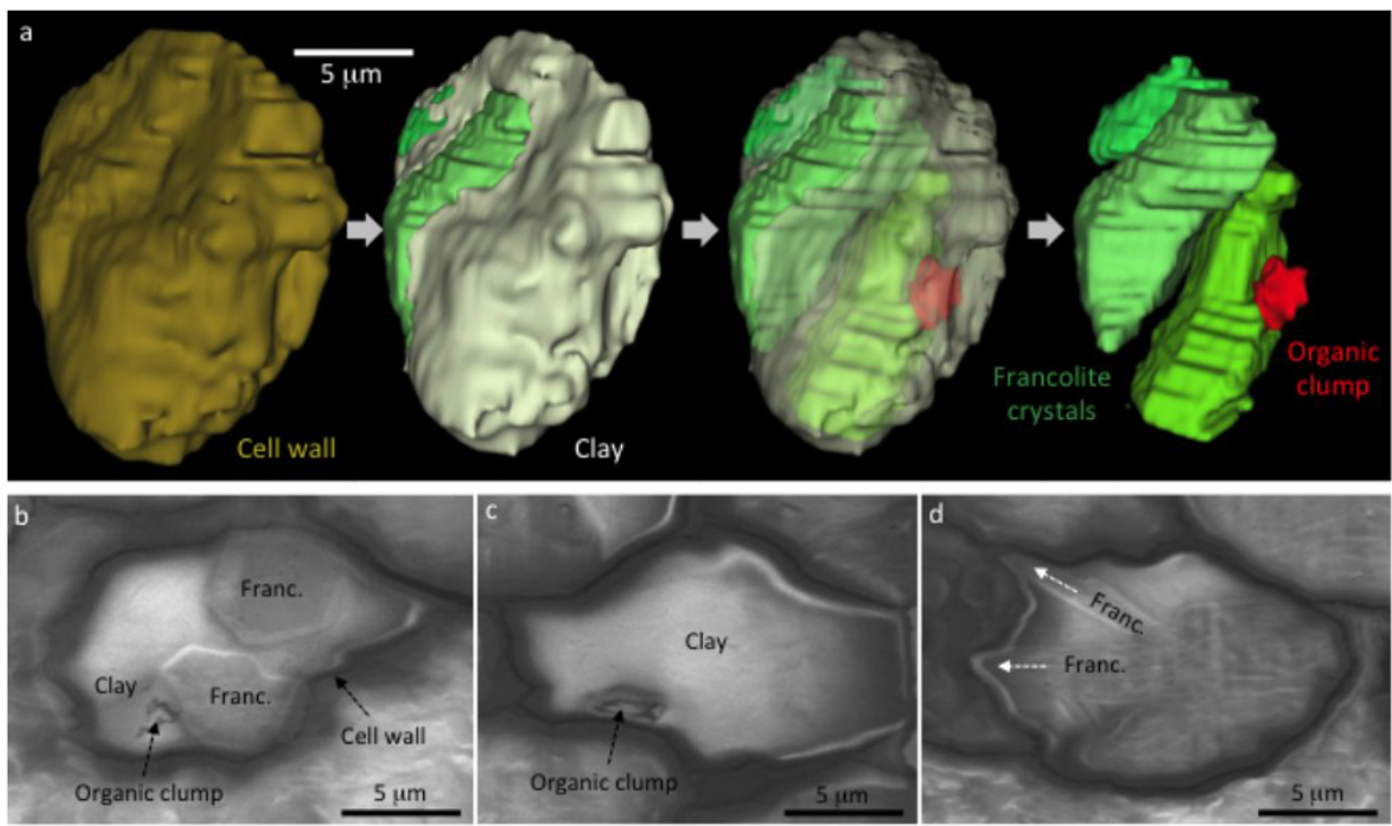

Figure $8 \mid$ Microfossil preservation quality in clay minerals. (a) 3D reconstruction of a prokaryote cell. Overview of the carbonaceous cell wall exterior is shown on the left. Next, the cell wall is removed to show the cell interior mineralized by clay (white) and three calcium phosphate (francolite) crystals (green). The clay portion is then made transparent to show that clays enclose degraded remains of putative cell contents (red). Finally (right), the clays are removed to show that the putative cell contents (organic clump) are not enclosed by francolite. (b) A single FIB-SEM slice through the microfossil reconstructed in (a), showing the $2 \mathrm{D}$ relationship between the cell wall, francolite, clay minerals, and the organic clump interpreted as putative cell contents. (c) A second example of a prokaryote cell with putative cell contents preserved in clay. (d) A prokaryote cell fossilized by a mixture of clay and francolite, showing how the growth of two elongate francolite crystals (arrows) caused modification of the cell wall. 
films of K-rich alumino-silicate, whereas more recalcitrant tissues are preserved as K-poor alumino-silicate ${ }^{6}$. Such clay mineral replication may suggest volatilization of carbonaceous material during metamorphism, with the anatomic differences in alumino-silicate chemistry $^{6}$ reflecting differences in volatilization potential of different organic substrates ${ }^{11,13}$. Furthermore, other clay minerals in the Burgess Shale (e.g., 3D infilling of Burgessia digestive tracts) may be replacements of early diagenetic carbonate minerals, an interpretation supported by the fact that alumino-silicates appear to replace carbonate in later cross-cutting veins ${ }^{11}$.

We reject a metamorphic origin for the clays in our Torridon material. The organic matter here is remarkably well conserved, and the burial temperatures appear to have been relatively low $\left(<100^{\circ} \mathrm{C}\right.$ according to ref. 48 , contrasting with $250-300^{\circ} \mathrm{C}$ for the Burgess Shale). Tectonic cleavage and mineral cleavage-alignments are lacking ${ }^{38}$, and our alumino-silicate phases are non-micaceous. Unlike the Burgess Shale, both carbonate minerals and cross-cutting alumino-silicate veins are also lacking. Any alignment of the nonmicaceous Torridon clay minerals is also highly localized and better explained by templated growth upon organic surfaces. These clay minerals frequently inter-finger with calcium phosphate that precipitated during early (pre-compaction) diagenesis, preventing compaction of the enclosed microfossils ${ }^{44}$. The infilling of microfossils by clay minerals (as shown here) is therefore likely to have been early diagenetic and pre-compactional. These features, plus the presence of nano-scale changes in clay mineral chemistry across remarkably well-preserved organic walls, point towards an authigenic origin for clay minerals infilling and surrounding microfossils in Torridon sediments.

Later diagenetic effects on these clay minerals likely included some increase in crystallinity and changes in composition and structure. The chamosite may have formed as an alteration product of berthierine upon burial diagenesis in excess of about $90-120^{\circ} \mathrm{C}^{50}$. This is consistent with our detection of mixtures of these minerals in our samples and with previous estimates of heating temperatures of the Torridon sediments ${ }^{48}$. Illite may have formed via diagenetic alteration of other (e.g., smectite or kaolinite) clays by K-rich water ${ }^{\text {cf.38. }}$. However, patches of amorphous illite encased within microfossils suggests a primary origin for at least some of this mineral phase.

An authigenic origin for both phosphates and microfossil-associated clays requires a mechanism that allows for near simultaneous precipitation within the Torridon lakes. Below we make some inferences about the prevailing environmental conditions.

The Torridon sediments have a markedly non-marine character $^{38,40-44}$, and the microfossils are thought to be indigenous to a succession of lake ecosystems ${ }^{44}$. Of these, the Diabaig lakes were evidently fed by rivers that cut through palaeo-hills of Lewisian basement and 1.2 Ga Stoer Group non-marine sediments ${ }^{48}$, while the younger Cailleach Head lakes were presumably fed by rivers carrying both Lewisian and reworked Stoer and Torridon sediment ${ }^{38}$. High levels of localized continental chemical weathering would have brought enrichment in biolimiting nutrients (e.g., P) and other mineral ions (e.g., $\mathrm{K}, \mathrm{Si}, \mathrm{Al}, \mathrm{Ca}, \mathrm{Mg}, \mathrm{Fe}$ ) to the Torridon lakes.

Phosphate ions were likely taken up by both benthic and planktonic primary producers, potentially encouraging microbial blooms. Under oxidizing conditions, phosphate will also have been adsorbed on the surfaces of iron oxides and hydroxides ${ }^{\text {c.51.51. }}$. Upon death of microbial blooms, organic matter sank to the sediment surface where it began to decompose. The resulting reducing conditions then encouraged the release of phosphate from organic matter. Anoxia, in turn, caused the reduction of iron oxides and associated desorption of additional phosphate ${ }^{52}$. Phosphate was concentrated in a thin layer above and below the sediment water interface, where supersaturation led to precipitation of cryptocrystalline francolite, containing both organic and clastic matter from this zone. Such organic decay tended to maintain $\mathrm{pH}$ at a level where phosphate precipitation was favoured over calcium carbonate ${ }^{51,53}$. The presence of an organic-rich 'seston' layer on the lake floor is inferred from the amorphous to clotted phosphate textures. Such a layer arguably resulted in a zone above the sediment water interface that was supersaturated with respect to phosphate, giving a pure phosphatic fabric that now grades downwards into more granular, clastic rich phosphate. Where this seston layer was absent, the phosphate formed just below the sediment surface, producing a granular texture.

Turning to the co-precipitation of silicate phases, we suggest that both $\mathrm{Si}$ and $\mathrm{Al}$ ions were delivered to the lakes from feldspar weathering, while the lack of sponges or diatoms at this time enabled raised concentrations of dissolved Si to be maintained ${ }^{\text {cf.54 }}$. Combined with low sulphate concentrations (meaning that iron was not sequestered as pyrite), this would have allowed early Fe-rich clay minerals such as berthierine to form in the suboxic zone. Biologically-mediated clay mineral authigenesis may have begun with the binding of metallic ions through electrostatic interaction with carboxyl, phosphoryl or hydroxyl groups contained within the polymers of cell walls, sheaths and other exuded extracellular material ${ }^{\text {e.g., }, 27,28,55}$. Such metal binding may inhibit autolytic activity within the organism after death ${ }^{55}$, enhancing morphological preservation ${ }^{7}$, and providing reactive surfaces and templates for authigenic mineral precipitation and growth $^{27,30}$.

The presence of Fe-rich minerals (often with minor $\mathrm{Mg}$ ) in direct contact with the outer envelopes of Torridon microfossils is consistent with $\mathrm{Fe}$ and $\mathrm{Mg}$ being the most reactive species in the porewater $^{\mathrm{cf.32,36}}$ and initially out-competing other cations such as $\mathrm{Ca}$ and $\mathrm{K}$ in binding to organic material. Fe (and to a certain extent $\mathrm{Mg}$ ) seem to have been particularly attracted to the outer margins of cells, vesicles and sheaths, all of which would have been rich in extracellular polymeric substances. Such substances are particularly adept at binding metal ions and nucleating phyllosilicates owing to their chain-like polysaccharide structure ${ }^{33}$. The new cation-rich sites would then have served as kinetically favourable sites for mineral nucleation and growth, potentially reacting directly with dissolved $\mathrm{Si}$ and $\mathrm{Al}$ or colloidal alumino-silicate species already present in the porewater. Amorphous and hydrous precursor phases probably formed first, with further growth occurring abiogenically due to the increased surface area provided by the initial grains ${ }^{\text {cf.28 }}$. Once Fe and $\mathrm{Mg}$ were exhausted, it seems plentiful $\mathrm{K}$ was present (from Kfeldspar albitization and weathering) to combine with the remaining $\mathrm{Si}$ and $\mathrm{Al}$, perhaps replacing less labile organic material and infilling areas such as partially empty cyst interiors. Phosphate likely precipitated during the latter stages of Fe-silicate precipitation and throughout $\mathrm{K}$-silicate precipitation, as evidenced by the relative zoning of each mineral phase. With time and diagenesis, dehydration and re-organisation into more crystalline phases then took place, preserving a cross section of early amorphous clays, later crystalline clays and phosphate.

It is notable that the Torridon microfossils differ from previously described phosphatic lagerstätten (e.g., Doushantuo-type ${ }^{3}$ ) in still containing a high percentage of original cellular organic material, rather than organisms being pseudomorphed by phosphate. In addition, most previously reported occurrences of fossil preservation in clay minerals also see co-precipitation of pyrite $e^{\text {e.g.6 }}$, whereas the Torridon lakes demonstrate a clay-phosphate association, with pyrite rarely seen within the phosphate nodules and bands. Co-precipitation of authigenic clays and phosphate is rather uncommon but has been reported from modern sulfate-depleted settings with particularly thick Fe-reduction zones ${ }^{46}$. Hence, this type of fossil preservation may provide a signature of low sulfate conditions in the rock record. This discovery now extends the geological range of microbially-mediated clay mineral precipitation by almost half a billion years. It also shows that specific micro-environments may be reflected by the types of clay minerals precipitated and preserved, providing new insights into early life and the early fossil record. 
of masks were added to segment individual components (e.g. mineral grains, cell walls, cell contents) of the microfossil assemblage. The resulting files were exported and loaded into SPIERSview ${ }^{58}$ to generate the $3 \mathrm{D}$ volume renderings. SPIERSview allows each individual masked component to be switched 'on' of 'off, or be made transparent, if necessary to better visualize adjacent components.

FIB extraction of ultrathin TEM lamellae. Study samples were standard uncovered polished geological thin sections. Prior to focused ion beam (FIB) milling, the thin sections were examined by optical microscopy, plus SEM in order to elucidate microfossil distributions and morphologies, and hence select the most appropriate targets for detailed study. Of great importance in the field of palaeobiology is that FIB preparation of TEM sections allows features just below the surface of the thin sections to be targeted, thus eliminating the risk of surface contamination (for example during diamond polishing) producing artifacts. A Zeiss Supra 1555 and Nikon Optiophot-2/ Optiophot-pol microscopes were used for SEM and optical microscopy respectively.

Two FEI Helios NanoLab duel beam FIB systems at Adelaide Microscopy, The University of Adelaide and the Electron Microscopy Unit of the University of New South Wales (UNSW) were used to prepare the TEM lamellae from polished thin sections. Electron beam imaging was used to identify microfossils of interest in the polished thin sections allowing site-specific TEM samples to be prepared. The TEM sections were prepared by a series of steps involving different beam energies and current $^{56}$, resulting in ultrathin wafers of c. $100 \mathrm{~nm}$ thickness. These TEM wafers were extracted using an ex-situ micromanipulator and deposited on continuouscarbon copper TEM grids (at UNSW) or an in-situ micromanipulator and placed on Omniprobe ${ }^{\circledR}$ copper TEM sample holders (at Adelaide).

TEM analysis of FIB-milled wafers. TEM data were obtained using a FEI Titan G2 80-200 TEM/STEM with ChemiSTEM Technology operating at $200 \mathrm{kV}$, plus a JEOL $2100 \mathrm{LaB}_{6}$ TEM operating at $200 \mathrm{kV}$ equipped with a Gatan Orius CCD camera and Tridiem energy filter. Both instruments were located in the Centre for Microscopy, Characterisation and Analysis (CMCA) at The University of Western Australia. HAADF (high angle annular dark-field) STEM images, EDS maps and spectra were obtained on the FEI Titan. Energy filtered (EFTEM) elemental maps were obtained on the JEOL 2100 using the conventional three-window technique, with energy windows selected to provide optimum signal-to-noise. Selected area electron diffraction (SAED) was performed on the JEOL 2100 using an aperture that selected a $200 \mathrm{~nm}$ diameter area of the sample.

Microprobe mineral analysis. Energy dispersive spectra were obtained on a JEOL $8530 \mathrm{~F}$ electron microprobe at CMCA with a beam energy of $15 \mathrm{keV}$ and beam current of $5 \mathrm{nA}$. Acquisition time was $40 \mathrm{~s}$ per spectrum with a fully focussed beam. Quantitative chemical maps were acquired by wavelength dispersive spectrometry on the same instrument, which is equipped with 5 tunable wavelength dispersive spectrometers. Operating conditions were 40 degrees take-off angle, beam energy of $15 \mathrm{keV}$ and beam current of $20 \mathrm{nA}$. The beam was fully focussed with a dwell time per pixel of $100 \mathrm{~ms}$ and a $0.3 \times 0.3 \mu \mathrm{m}$ pixel dimension. The elements were acquired using analyzing crystals: $\mathrm{LiF}$ for $\mathrm{Fe} \mathrm{K} \alpha$; PET for $\mathrm{P} \mathrm{K} \alpha, \mathrm{K} \mathrm{K} \alpha$, and $\mathrm{Ca} \mathrm{K} \alpha$; TAP for $\mathrm{Na}$ $\mathrm{K} \alpha, \mathrm{Mg} \mathrm{K} \alpha$, and Si $\mathrm{K} \alpha$. The standards employed for instrument calibration were commercially available metals, oxides, silicates and phosphates. On peak counting times were 20 seconds and mean atomic number background corrections were used throughout. The algorithm utilized was that of Armstrong ${ }^{57}$. Image processing was performed off-line with the CalcImage ${ }^{\circledR}$ software.

FIB-SEM elemental mapping and nano-tomography. Sequential FIB milling, SEM imaging and analysis was performed on the FEI Helios NanoLab dual-beam instrument at Adelaide Microscopy, plus a Zeiss Neon 40 dual-beam instrument at the Naval Postgraduate School, Monterey, California, and a Zeiss Auriga Crossbeam instrument at the Electron Microscopy Unit, UNSW. Although three different instruments were used, the protocol for achieving high quality images and elemental maps was very similar. The protocol for the Helios NanoLab instrument was as follows. Regions of interest (ROI) were located using electron beam imaging. A protective Pt layer $(\sim 0.5$ to $1 \mu \mathrm{m}$ thick $)$ was then deposited over the entire ROI and a trench was milled using a $\sim 9 \mathrm{nA}$ ion beam at the leading edge of the ROI. This trench must be around $20 \mu \mathrm{m}$ wider in the $x$ direction than the ROI, and must have sufficient depth in both $y$ and $z$ directions so that clear images of the face of interest can be subsequently obtained using the electron beam. Two further narrow trenches $(\sim 10 \mu \mathrm{m}$ each side) were milled along the two sides of the ROI. These are required to collect the debris sputtered from the ROI by the ion beam milling process. A further conductive Pt strip was often added to the tail end of the ROI at this stage to attempt to minimize sample charging. The front and side faces of the ROI were then cleaned (with sequentially reduced ion beam currents), repositioned, refocused and imaged using the electron beam. Subsequent milling and imaging was then fully automated and key parameters were somewhat dependent on the sample composition and instrument type. Electron beam voltage for imaging varied between about $800 \mathrm{~V}$ and $5 \mathrm{kV}$, ion beam currents for milling were 2-3 nA, step sizes were between $75 \mathrm{~nm}$ and $200 \mathrm{~nm}$, and image capture times were around 30 seconds per frame.

The sequential slicing and imaging could be stopped at any point and an energydispersive X-ray detector inserted to perform elemental mapping of a single FIBmilled face. In some cases, dedicated trenches were milled in order to obtain elemental maps of microfossils that were not sequentially milled for 3D analysis.

1. Barghoorn, E. S. \& Tyler, S. A. Microorganisms from the Gunflint Chert. Science 147, 563-577 (1965).

2. Briggs, D. E. G., Raiswell, R., Bottrell, S. H., Hatfield, D. \& Bartels, C. Controls on the pyritization of exceptionally preserved fossils: An analysis of the lower Devonian Hunsruck slate of Germany. Am. J. Sci. 296, 633-663 (1996).

3. Xiao, S., Zhang, Y. \& Knoll, A. H. Three-dimensional preservation of algae and animal embryos in a Neoproterozoic phosphorite. Nature 391, 553-558 (1998)

4. Butterfield, N. J. Secular distribution of Burgess Shale-type preservation. Lethaia 28, 1-13 (1995).

5. Gabbott, S. E. Taphonomy of the Ordovician Soom Shale lagerstatte: an example of soft tissue preservation in clay minerals. Palaeontol. 41, 631-667 (1998).

6. Orr, P. J., Briggs, D. E. G. \& Kearns, S. L. Cambrian Burgess Shale animals replicated in clay minerals. Science 281, 1173-1175 (1998).

7. Petrovich, R. Mechanisms of fossilization of the soft-bodied and lightly armored faunas of the Burgess Shale and some other classical localities. Am. J. Sci. 301, 683-726 (2001)

8. Gabbott, S. E., Norry, M. J., Aldridge, R. J. \& Theron, J. N. Preservation of fossils in clay minerals; a unique example from the Upper Ordovician Soom Shale, South Africa. Proc. York. Geol. Soc. 53, 237-244 (2001).

9. Martin, D., Briggs, D. G. \& Parkes, R. J. Experimental attachment of sediment particles to invertebrate eggs and the preservation of soft-bodied fossils. J. Geol. Soc. Lon. 161, 735-738 (2004).

10. Zhu, M., Babcock, L. E. \& Steiner, M. Fossilization modes in the Chengjiang Lagerstatte (Cambrian of China): testing the roles of organic preservation and diagenetic alteration in exceptional preservation. Palaeogeog. Palaeoclim. Palaeoecol. 220, 31-46 (2005).

11. Butterfield, N. J., Balthasar, U. \& Wilson, L. A. Fossil diagenesis in the Burgess Shale. Palaeontol. 50, 537-543 (2007).

12. Zhang, X. \& Briggs, D. E. G. The nature and significance of the appendages of Opabina from the Middle Cambrian Burgess Shale. Lethaia 40, 161-173 (2007)

13. Page, A., Gabbott, S. E., Wilby, P. R. \& Zalasiewicz, J. A. Ubiquitous Burgess Shalestyle "clay templates" in low-grade metamorphic mudrocks. Geology 36, 855-858 (2008).

14. Callow, R. T. \& Brasier, M. D. A solution to Darwin's dilemma of 1859: exceptional preservation in Salter's material from the late Ediacaran Longmyndian Supergroup, England. J. Geol. Soc. Lon. 166, 1-4 (2009).

15. Ushatinskaya, G. T. Preservation of living organic structures in unicellular and multicellular organisms in the fossil state. Palaeontol. J. 43, 928-939 (2009).

16. Anderson, E. P., Schiffbauer, J. D. \& Xiao, S. Taphonomic study of Ediacaran organic-walled fossils confirms the importance of clay minerals and pyrite in Burgess Shale-type preservation. Geology 39, 643-646 (2011).

17. Laflamme, M., Schiffbauer, J. D., Narbonne, G. M. \& Briggs, D. E. G. Microbial biofilms and the preservation of the Ediacara biota. Lethaia 44, 203-213 (2011)

18. Cai, Y., Schiffbauer, J. D., Hua, H. \& Xiao, S. Preservational modes in the Ediacaran Gaojiashan Lagerstatte: Pyritization, aluminosilicification, and carbonaceous compression. Palaeogeog. Palaeoclim. Palaeoecol. 326-328, 109-117 (2012)

19. Darroch, S. A. F., Laflamme, M., Schiffbauer, J. D. \& Briggs, D. E. G. Experimental formation of a microbial death mask. Palaios 27, 293-303 (2012).

20. Galvez, M. E. et al. Morphological preservation of carbonaceous plant fossils in blueschist metamorphic rocks from New Zealand. Geobiol. 10, 118-129 (2012).

21. Meyer, M., Schiffbauer, J. D., Xiao, S., Cai, Y. \& Hua, H. Taphonomy of the Upper Ediacaran enigmatic ribbonlike fossil Shaanxilithes. Palaios 27, 354-372 (2012)

22. Gehling, J. G. Microbial mats in terminal Proterozoic siliciclastics: Ediacaran death masks. Palaios 14, 40-57 (1999).

23. Urrutia, M. M. \& Beveridge, T. J. Formation of fine-grained metal and silicate precipitates on a bacterial surface (Bacillus subtilis). Chem. Geol. 116, 261-280 (1994).

24. Mera, M. U. \& Beveridge, T. J. Mechanism of silicate binding to the bacterial cell wall in Bacillus subtilis. J. Bacteriol. 175, 1936-1945 (1993).

25. Fiore, S., Dumontet, S., Huertas, F. J. \& Pasquale, V. Bacteria-induced crystallization of kaolinite. Appl. Clay Sci. 53, 566-571 (2011).

26. Ferris, F. G., Fyfe, W. S. \& Beveridge, T. J. Bacteria as nucleation sites for authigenic minerals in a metal-contaminated lake sediment. Chem. Geol. 63, 225-232 (1987).

27. Fortin, D., Ferris, F. G. \& Scott, S. D. Formation of Fe-silicates and Fe-oxides on bacterial surfaces in samples collected near hydrothermal vents on the Southern Explorer Ridge in the northeast Pacific Ocean. Am. Mineral. 83, 1399-1408 (1998).

28. Konhauser, K. O. \& Urrutia, M. M. Bacterial clay authigenesis: a common biogeochemical process. Chem. Geol. 161, 399-413 (1999).

29. Konhauser, K. O. Introduction to Geomicrobiology (Blackwell Publishing, Oxford, 2007). 
30. Konhauser, K. O., Fyfe, W. S., Ferris, F. G. \& Beveridge, T. J. Metal sorption and mineral precipitation by bacteria in two Amazonian river systems: Rio Solimoes and Rio Negro, Brazil. Geology 21, 1103-1106 (1993).

31. Souza-Egipsy, V., Wierzchos, J., Ascaso, C. \& Nealson, K. H. Mg-silica precipitation in fossilization mechanisms of sand tufa endolithic microbial community, Mono Lake (California). Chem. Geol. 217, 77-87 (2005).

32. Pacton, M. et al. Going nano: a new step towards understanding the processes governing freshwater ooid formation. Geology 40, 547-550 (2012).

33. Ueshima, M. \& Tazaki, K. Possible role of microbial polysaccharides in nontronite formation. Clays Clay Min. 49, 292-299 (2001).

34. Kawana, M. \& Tomita, K. Microbial biomineralization in weathered volcanic ash deposit and formation of biogenic minerals by experimental incubation. Am. Mineral. 86, 400-410 (2001).

35. Kim, J., Dong, H., Seabaugh, J., Newell, S. W. \& Eberl, D. D. Role of microbes in the smectite-to-illite reaction. Science 303, 830-832 (2004).

36. Ferris, F. G. \& Beveridge, T. J. Physiochemical roles of soluble metal cations in the outer membrane of Escherichia coli K-12. Can J. Microbiol. 32, 594-601 (1986).

37. Peach, B. N., Horne, J., Gunn, W., Clough, C. T. \& Hinxman, L. W. The geological structure of the North-West Highlands of Scotland. Mem. Geol. Surv, Great. Brit. (1907).

38. Stewart, A. D. The Torridon Group. Geol. Soc. Lon. Mem. 24, 29-46 (2002).

39. Turnbull, M. J. M., Whitehouse, M. J. \& Moorbath, S. New isotopic age determinations for the Torridonian, NW Scotland. J. Geol. Soc. Lon. 153, 955-964 (1996).

40. Prave, A. R. Life on land in the Proterozoic: Evidence from the Torridonian rocks of northwest Scotland. Geology 30, 811-814 (2002).

41. Parnell, J., Boyce, A. J., Mark, D., Bowden, S. \& Spinks, S. Early oxygenation of the terrestrial environment during the Mesoproterozoic. Nature 468, 290-293 (2010).

42. Callow, R. H. T., Battison, L. \& Brasier, M. D. Diverse microbially induced sedimentary structures from 1 Ga lakes of the Diabaig Formation, Torridon Group, northwest Scotland. Sedim. Geol. 239, 117-128 (2011).

43. Strother, P. K., Battison, L., Brasier, M. D. \& Wellman, C. H. Earth's earliest nonmarine eukaryotes. Nature 473, 505-509 (2011).

44. Battison, L. \& Brasier, M. D. Remarkably preserved prokaryote and eukaryote microfossils within $1 \mathrm{Ga}$-old lake phosphates of the Torridon Group, NW Scotland. Precamb. Res. 196-197, 204-217 (2012).

45. Downs, R. T. \& Hall-Wallace, M. The American Mineralogist Crystal Structure Database. Am. Mineral. 88, 247-250 (2003).

46. Pe-Piper, G. \& Weir-Murphy, S. Early diagenesis of inner-shelf phosphorite and iron-silicate minerals, Lower Cretaceous of the Orpheus graben, southeastern Canada: Implications for the origin of chlorite rims. AAPG Bull. 92, 1153-1168 (2008)

47. Bailey, S. W. Odinite, a new dioctahedral-trioctahedral $\mathrm{Fe}^{3+}$-rich $1: 1$ clay mineral. Clay Min. 23, 237-247 (1988).

48. Stewart, A. D. \& Parker, A. Palaeosalinity and environmental interpretation of red beds from the late Precambrian ('Torridonian') of Scotland. Sedim. Geol. 22, 229-241 (1979).

49. Briggs, D. E. G., Kear, A. J., Martill, D. M. \& Wilby, P. R. Phosphatization of softtissue in experiments and fossils. J. Geol. Soc. Lon. 150, 1035-1038 (1993).

50. Aagaard, P., Jahren, J. S., Harstad, A. O., Nilsen, O. \& Ramm, M. Formation of grain-coating chlorite in sandstones. Laboratory synthesized vs. natural occurrences. Clay Min. 35, 261-269 (2000).

51. Follmi, K. B. The phosphorus cycle, phosphogenesis and marine phosphate-rich deposits. Earth Science Rev. 40, 55-124 (1996).

52. Froelich, P. N. et al. Early diagenesis of organic matter in Peru continental margin sediments: Phosphorite precipitation. Mar. Geol. 80, 309-343 (1988)
53. Ruttenburg, K. C. The Global Phosphorus Cycle. Treatise Geochem. 8, 585-643 (2002).

54. Maliva, R. G., Simonson, B. M. \& Knoll, A. H. Secular changes in the Precambrian silica cycle: insights from chert petrology. Geol. Soc. Am. Bull. 117, 835-845 (2005).

55. Ferris, F. G., Fyfe, W. S. \& Beveridge, T. J. Metallic ion binding by Bacillus subtilis: Implications for the fossilization of microorganisms. Geology 16, 149-152 (1988).

56 . Wacey, D. et al. Taphonomy of very ancient microfossils from the $\sim 3400 \mathrm{Ma}$ Strelley Pool Formation and $\sim 1900$ Ma Gunflint Formation: New insights using a focused ion beam. Precamb. Res. 220-221, 234-250 (2012).

57. Armstrong, J. T. [Quantitative analysis of silicate and oxide materials: comparison of Monte-Carlo, ZAF and Phi-Rho-Z procedures] Microbeam Analysis-1988 [Newbury, D. E. (ed.)] [239-246] (San Francisco Press, San Francisco,1988).

58. Sutton, M. D., Garwood, R. J., Siveter, D. J. \& Siveter, D. J. SPIERS and VAXML: a software toolkit for tomographic visualization and a format for virtual specimen interchange. Palaeontol. Elect. 15, 5T, 14 pp (2012).

\section{Acknowledgments}

The authors acknowledge the facilities, scientific and technical assistance of the AMMRF at: the Centre for Microscopy Characterisation and Analysis, The University of Western Australia; Adelaide Microscopy, The University of Adelaide; and the Electron Microscopy Unit, The University of New South Wales. These facilities are funded by the Universities, State and Commonwealth Governments. We thank Dr. Christoph Mitterbauer at FEI's NanoPort Europe for his assistance in acquiring the data presented in Figure 4b. DW is supported by an Australian Research Council grant to the Centre of Excellence for Core to Crust Fluid Systems (CCFS). This is contribution 484 from CCFS (http://www.ccfs.mq.edu. au)

\section{Author contributions}

T.C., P.S. and M.D.B. performed the field mapping and collected samples. M.D.B., P.S., T.C and D.W. carried out the petrography. S.M., L.G. and C.K. performed the FIB and SEM work. M.S. performed the TEM analyses. M.R. performed the microprobe analyses. D.W. performed the sample preparation, data processing and visualisation. D.W. and M.D.B. interpreted the data and wrote the paper. All authors discussed the results and commented on the manuscript.

\section{Additional information}

Supplementary information accompanies this paper at http://www.nature.com/ scientificreports

Competing financial interests: The authors declare no competing financial interests. How to cite this article: Wacey, D. et al. Enhanced cellular preservation by clay minerals in 1 billion-year-old lakes. Sci. Rep. 4, 5841; DOI:10.1038/srep05841 (2014).

This work is licensed under a Creative Commons Attribution-NonCommercialNoDerivs 4.0 International License. The images or other third party material in this article are included in the article's Creative Commons license, unless indicated otherwise in the credit line; if the material is not included under the Creative Commons license, users will need to obtain permission from the license holder in order to reproduce the material. To view a copy of this license, visit http:// creativecommons.org/licenses/by-nc-nd/4.0/ 